\title{
Extraction and Antioxidative Activity of Essential Oil From Star Anise (IIlicium verum)
}

\author{
Y.C. WONG*, P.P. LEE and W.A. WAN NURDIYANA \\ Faculty of Agro Based Industry, Universiti Malaysia Kelantan, \\ Jeli Campus, Locked Bag 100, 17600 Jeli, Kelantan, Malaysia. \\ ${ }^{*}$ Corresponding author E-mail : yeeching@umk.edu.my
}

http://dx.doi.org/10.13005/ojc/300329

(Received: June 05, 2014; Accepted: July 14, 2014)

\begin{abstract}
Star anise (Illiciumverum) essential oil was extracted using solvent extraction method. The extraction yields and antioxidant activities of essential oils at different extraction times $(1,3,5,7$ and 9 days) and temperatures $\left(30,40,50,60,70^{\circ} \mathrm{C}\right)$ were studied. The results showed that the highest yield of essential oil was $8.56 \%$ by extracting star anise at $60 \mathrm{p} \mathrm{C}$ for 7 days. The antioxidant activities of the extracted star anise essential oils were investigated using 2, 2-diphenyl-1-picrylhydrazyl (DPPH) assay on Thin Layer Chromatography (TLC) plates and DPPH radical scavenging method. The results showed that at least two different bands with antioxidant activity with different polarity were appeared on the TLC plates after spraying with DPPH and incubated for 30 minutes. The highest antioxidant activity of star anise essential oil was obtained when the sample was extracted at $60 \mathrm{p}$ $\mathrm{C}$ for 1 day $\left(\mathrm{EC}_{50}\right.$ value $\left.=0.089 \pm 0.05 \mathrm{mg} / \mathrm{ml}\right)$. HPLC analysis showed that the concentration $(\%)$ of trans-Anethole present in the essential oils extracted at varied extraction times and temperatures was ranged from $77.29 \%$ to $91.87 \%$.Gas Chromatography-Mass Spectrometry (GC-MS) analysis was also done on a sample of star anise essential oil and a distinctive peak at retention time 13.84 minutes with peak area $100 \%$ was found to be Estragole compound. Anethole compound was also found to be present at two peaks.
\end{abstract}

Key words: solvent extraction, star anise essential oil, Extraction yield, antioxidant activity, trans-Anethole.

\section{INTRODUCTION}

Long term and extensive use of synthetic antioxidant such as butylatedhydroxytoluene $(\mathrm{BHT})$ and butylatedhydroxyanisole (BHA) have been proven to cause carcinogenic effects in living organisms ${ }^{1-3}$. Due to the potential side effects of synthetic antioxidants, essential oil which derived from organic products can be served as an alternative source for the further improvement of synthetic antioxidant. Star anise (Illiciumverum) is a small star-shaped fruit of an evergreen of the Illiciaceae family ${ }^{4}$. This fruit is classified as a spice and it looks like a symmetrical eight-pointed star ${ }^{5}$. Essential oil of star anise has a sweetish, anise flavour and a highly aromatic odour. Due to its high level of phenolic volatile oils, star anise essential oil 
could be used as a potential alternative antioxidant for synthetic antioxidant.

The objectives of this study were to extract essential oil from star anise using solvent extraction method, to determine the yields and antioxidant activities of essential oils at different extraction times and temperatures, to determine the quantity of transAnethole present in star anise essential oil using high performance liquid chromatography (HPLC), as well as tovalidate the presence of Anethole in star anise using Gas Chromatography-Mass Spectrometry (GC-MS).

\section{MATERIALS AND METHOD}

\section{Collection of star anise}

Star anise dried fruits were purchased from Tong Chun Tang traditional medicine store, Batang Kali, Selangor. The star anise fruits originated from Guangxi province, China. Star anise fruits were stored in plastic bags covered with newspapers to protect them from direct light. Finally, they were kept at room temperature.

\section{Soaking of star anise}

$50 \mathrm{~g}$ of dried star anise fruits were weighed using analytical balance (Model: ATX 224, Shimadzu, Japan). The whole star anise fruits were divided into separated carpels and were blended using blender (Model: MX-800S, Panasonic) for 20 seconds. The ground star anise was dissolved in $250 \mathrm{ml}$ of absolute ethanol (ratio of crushed star anise to the ethanol was $1: 5, w / v)$ for a given time $(1,3,5,7$ and 9 days) at different temperatures $\left(30,40,50,60\right.$ and $\left.70^{\circ} \mathrm{C}\right)$.

\section{Extraction of essential oil from star anise}

This method was adapted from the work of Thuat and Ngoc (2010) with some modifications ${ }^{6}$. After the extraction time, the solution and solid part were separated by filtration using Whatman filter paper. The brown coloured filtrate was concentrated to volume of $100 \mathrm{ml}$ using rotary evaporator (Model: Hei-vap Precision MLG3B, Germany) at $40{ }^{\circ} \mathrm{C}$. The $100 \mathrm{ml}$ concentrate was mixed with $100 \mathrm{ml}$ of petroleum ether and $100 \mathrm{ml}$ of $\mathrm{dH}_{2} \mathrm{O}$. The mixture was shook vigorously. After some time of settling, the petroleum ether solution (the upper layer) was dried over anhydrous $\mathrm{Na}_{2} \mathrm{SO}_{4}$. The petroleum ether solvent was removed using rotary evaporator to obtain essential oil. All the essential oils were stored in bijou glass bottles in dark condition at $4{ }^{\circ} \mathrm{C}$ before analysis.

\section{Qualitative test using DPPH on TLC}

This test was adapted from the work of Saleh and research group (2010) with a slight modification $^{7} .10 \mu \mathrm{l}$ of oil sample was spotted on a 10 $x 10 \mathrm{~cm}$ silica glass plate. The plate was developed into 95:5, v/v toluene/ ethyl acetate as a mobile phase. After evaporation of the solvent, the plate was sprayed with $0.004 \%$ solution of 2,2-diphenyl1-picrylhydrazyl (DPPH). The antioxidant activity was detected after 30 minutes. The yellow spots appeared from the reduction of DPPH was taken as positive results.

\section{Quantitative test using DPPH scavenging assay}

The antioxidant activity of star anise essential oil was measured in term of radical scavenging ability, using the stable free DPPH radical. This method was adapted from the work of Brand-Williams, Cuvelier and Berset (1995) with some modifications [8]. Stock solution $(1 \mathrm{mg} / \mathrm{ml})$ was twofold diluted to different concentrations $(0.0625$, $0.125,0.25,0.5$ and $1 \mathrm{mg} / \mathrm{ml}$ ) with methanol. An aliquot of each dilution, about $1 \mathrm{ml}$ was mixed with $1 \mathrm{ml}$ of $0.004 \%$ methanolic DPPH ( $0.004 \mathrm{~g}$ of DPPH in $100 \mathrm{ml}$ of methanol). The mixture was vortexed and incubated in the dark at room temperature for 30 minutes. The absorbance was measured at $517 \mathrm{~nm}$ against a blank (1 $\mathrm{ml}$ of methanol with 1 $\mathrm{ml}$ of methanolic DPPH without the test oil) using spectrophotometer (Model: Genesys 20 4001/4). The radical scavenging activity or antioxidant activity (\%) of each concentration of oil was calculated using the following formula:

Antioxidant activity $(\%)=\left[\left(O D_{\text {blank }}-O D_{\text {assay }}\right) /\left(O D_{\text {blank }}\right)\right.$ ] $x 100 \%$

The test was performed in triplicate. The antioxidant activities of the essential oils were expressed as $\mathrm{EC}_{50}$, defined as the oil concentration in $\mathrm{mg} / \mathrm{ml}$ required to scavenge $50 \%$ of the DPPH free radical. BHT was used as positive control.

\section{HPLC analysis}

HPLC analysis was performed using Prominence, Shimadzu, Japan. The separation 
column was Hypersil C18 column (250 mm x 4.6 $\mathrm{mm}, 5 \mu \mathrm{m})$. Essential oil was dissolved in acetonitrile $(1 \mathrm{mg} / \mathrm{ml})$. The sample was filtered using syringe with $0.45 \mu \mathrm{m}$ filters prior to being filled into the vial. 5 ul of sample was injected into HPLC system and the injector temperature was $30^{\circ} \mathrm{C}$. A gradient elution system using mobile phase of $15 \%-65 \%$ of acetonitrile with a flow rate of $1 \mathrm{ml} / \mathrm{min}$ for 45 minutes was used to identify the compounds present in the star anise essential oil.The detection wavelength was $275 \mathrm{~nm}$.GC-MS analysis of the star anise sample was also done using GCMS 5977A from Agilent Technologies.

\section{RESULTS AND DISCUSSION}

\section{The extraction yields of essential oils}

Maximum yield of star anise essential oil $(8.56 \%)$ could be obtained by soaking star anise at $60 \mathrm{p} \mathrm{C}$ for 7 days (Table 1). In contrast, extraction of essential oil at temperature of $30 p \mathrm{C}$ for 1 day gave minimum yield of essential oil ( $4.62 \%)$. It was about $46.03 \%$ less of extraction yield compared to the sample extracted at $60^{\circ} \mathrm{C}$ for 7 days.

There was contradictory report from previous researchers. From the previous study done by Ngoc (2006), dried star anise fruits have an essential oil content of 8-10\% ${ }^{9}$. The extraction yield of star anise essential oils in this study was 4.62-8.56\%, which was lower than that of extracted in previous study done by Ngoc. Different extraction yield of essential oil content might be due to several factors such as different geographical locations of the botanical materials, varying in cultivation condition, climate as well as post-harvest factors ${ }^{10}$.

Besides, it was observed that the yield of essential oil increased slightly with increasing extraction time and temperature until a certain point. This result was in accordance with Dent and coworkers' (2012) study, reflected that yield increased with increasing extraction temperature and extraction time ${ }^{11}$. At temperature of $30^{\circ} \mathrm{C}$, the extraction yield increased gradually with days. This result was in accordance with Kumar's previous study (2010), stated that the longer the extraction time, the longer the contact time of the plant material with the solvent and hence more yields of complete oil ${ }^{12}$. For temperature of $40^{\circ} \mathrm{C}$ and $70^{\circ} \mathrm{C}$, the extraction yields decreased when star anise soaked for more than 5 days. Same behavior was observed at temperature of $50^{\circ} \mathrm{C}$ and $60^{\circ} \mathrm{C}$, the yields decreased with an increase in extraction time at 9 days. This may be due to the loss of solvent by evaporation when extraction time and temperature increased simultaneously during extraction.

Table 1: Extraction yields at different extraction times and temperatures

\begin{tabular}{llllll}
\hline \multirow{2}{*}{$\begin{array}{l}\text { Extraction } \\
\text { time (days) }\end{array}$} & \multicolumn{5}{c}{ Extraction yields (\%) } \\
\cline { 2 - 6 } & $\mathbf{3 0 ^ { \circ } \mathbf { C }}$ & $\mathbf{4 0}^{\circ} \mathbf{C}$ & $\mathbf{5 0}^{\circ} \mathbf{C}$ & $\mathbf{6 0}^{\circ} \mathbf{C}$ & $\mathbf{7 0}^{\circ} \mathbf{C}$ \\
\hline 1 & 4.62 & 4.71 & 5.07 & 7.75 & 6.79 \\
3 & 5.34 & 7.81 & 7.85 & 7.88 & 7.17 \\
5 & 7.56 & 8.24 & 8.00 & 7.99 & 7.92 \\
7 & 7.65 & 8.10 & 8.48 & 8.56 & 7.53 \\
9 & 7.89 & 8.20 & 7.15 & 7.11 & 7.02 \\
\hline
\end{tabular}

Table 2: Qualitative DPPH assay on TLC of the 25 samples studied

\begin{tabular}{lccccc}
\hline \multirow{2}{*}{ Extraction } & \multicolumn{5}{c}{ Observation } \\
\cline { 2 - 6 } time (days) & $\mathbf{3 0} \mathrm{C}$ & $\mathbf{4 0} 0^{\circ} \mathrm{C}$ & $\mathbf{5 0} \mathrm{C}$ & $\mathbf{6 0}{ }^{\circ} \mathrm{C}$ & $\mathbf{7 0 ^ { \circ } \mathrm { C }}$ \\
\hline 1 & + & + & + & $+^{*}$ & $+^{*}$ \\
3 & + & + & + & $+^{*}$ & $+^{*}$ \\
5 & + & + & + & $+^{*}$ & $+^{*}$ \\
7 & + & + & + & $+^{*}$ & $+^{*}$ \\
9 & + & + & + & $+^{*}$ & $+^{*}$ \\
\hline
\end{tabular}

*The degree of activity was determined qualitatively from observation of the yellow intensity: weak $(+)$ and strong $\left(+^{*}\right)$.

Table 3: Number of antioxidant bands present in the star anise essential oils

\begin{tabular}{lccccc}
\hline \multirow{2}{*}{$\begin{array}{l}\text { Extraction } \\
\text { time (days) }\end{array}$} & \multicolumn{5}{c}{ Number of antioxidant bands } \\
\cline { 2 - 6 } & $\mathbf{3 0 ^ { \circ } \mathbf { C }}$ & $\mathbf{4 0 ^ { \circ } \mathbf { C }}$ & $\mathbf{5 0 ^ { \circ } \mathbf { C }}$ & $\mathbf{6 0 ^ { \circ } \mathbf { C }}$ & $\mathbf{7 0}^{\circ} \mathbf{C}$ \\
\hline 1 & 3 & 3 & 3 & 3 & 3 \\
3 & 3 & 2 & 3 & 3 & 3 \\
5 & 2 & 3 & 3 & 3 & 3 \\
7 & 3 & 3 & 3 & 3 & 3 \\
9 & 3 & 3 & 2 & 2 & 3 \\
\hline
\end{tabular}


Table 4: Antioxidant activity (\%) of each concentration of star anise essential oils

Samples Concentration $(\mathrm{mg} / \mathrm{ml}) \quad \mathrm{AA}^{*}(\%) \pm \mathrm{SE}$

$1(30)$

(n)

$3(30)$

$7(30)$

9 (30)

1 (40)

(40)

5 (40)

7 (40)

0.2500

0.1250

0.0625

1.0000

0.5000

0.2500

0.1250

0.0625

1.0000

0.5000

0.2500

0.1250

0.0625

1.0000

0.5000

0.2500

0.1250

0.0625

1.0000

0.5000

0.2500

0.1250

0.0625

1.0000

0.5000

0.2500

0.1250

0.0625

1.0000

0.5000

0.2500

0.1250

0.0625

1.0000

$37.09 \pm 1.32$
$9(40)$

1.0000

0.5000

0.2500

0.1250

0.0625

1.0000

0.5000

0.2500

0.1250

0.0625

$3(50)$

1.0000

0.5000

0.2500

0.5000

0.2500

0.1250

0.0625
$30.57 \pm 1.47$

$17.74 \pm 1.18$

$12.04 \pm 0.80$

$50.92 \pm 0.10$

$42.55 \pm 0.36$

$33.78 \pm 0.28$

$20.40 \pm 0.21$

$7.57 \pm 0.36$

$54.15 \pm 1.42$

$34.61 \pm 0.38$

$20.41 \pm 0.56$

$8.30 \pm 1.59$

$2.38 \pm 0.22$

$58.29 \pm 1.00$

$46.95 \pm 1.37$

$42.24 \pm 1.49$

$27.84 \pm 1.32$

$21.53 \pm 0.98$

$69.55 \pm 0.40$

$45.52 \pm 0.66$

$27.02 \pm 0.87$

$15.92 \pm 0.71$

$8.94 \pm 1.15$

$73.50 \pm 1.17$

$58.34 \pm 0.36$

$33.84 \pm 0.84$

$17.01 \pm 0.97$

$11.76 \pm 1.50$

$71.55 \pm 1.51$

$51.60 \pm 0.70$

$29.87 \pm 1.78$

$13.50 \pm 0.46$

$6.68 \pm 1.30$

$65.35 \pm 0.96$

$48.74 \pm 0.65$

$42.20 \pm 0.32$

$33.30 \pm 0.73$

$27.85 \pm 1.28$
0.1250

0.0625

$5(50) \quad 1.0000$

0.5000

0.2500

0.1250

0.0625

1.0000

0.5000

0.2500

0.1250

0.0625

$9(50)$

1.0000

0.5000

0.2500

0.1250

0.0625

$1(60)$

1.0000

0.5000

0.2500

0.1250

0.0625

1.0000

0.5000

0.2500

0.1250

$5(60)$

1.0000

0.5000

0.2500

0.1250

0.0625

7 (60)
0.0625
$72.70 \pm 1.22$

$45.22 \pm 0.78$

$23.16 \pm 1.12$

$18.00 \pm 0.35$

$8.00 \pm 0.49$

$75.54 \pm 0.57$

$69.88 \pm 1.08$

$69.47 \pm 0.52$

$55.87 \pm 0.47$

$39.76 \pm 1.24$

$76.58 \pm 0.66$

$74.49 \pm 0.62$

$61.99 \pm 1.05$

$53.16 \pm 1.99$

$34.53 \pm 0.80$

$75.26 \pm 0.88$

$69.07 \pm 0.73$

$65.58 \pm 0.44$

$48.46 \pm 1.23$

$35.79 \pm 1.10$

$72.51 \pm 0.31$

$68.67 \pm 1.83$

$66.27 \pm 0.93$

$46.54 \pm 1.13$

$32.72 \pm 1.55$

$77.43 \pm 0.97$

$76.73 \pm 1.73$

$73.34 \pm 0.49$

$57.16 \pm 1.07$

$35.19 \pm 0.82$

$77.76 \pm 0.15$

$67.10 \pm 1.03$

$62.62 \pm 0.74$

$57.76 \pm 1.16$

$42.25 \pm 1.17$

$76.71 \pm 0.68$

$72.26 \pm 1.44$

$53.81 \pm 1.13$

$30.61 \pm 0.56$

$16.03 \pm 1.22$

$77.70 \pm 0.60$

$72.30 \pm 0.27$

$67.50 \pm 0.50$

$41.78 \pm 1.69$

$25.72 \pm 1.41$

$72.87 \pm 0.25$

$72.44 \pm 0.61$

$61.35 \pm 0.19$

$39.84 \pm 1.17$

$30.46 \pm 1.31$ 


$\begin{array}{lll}9(60) & 1.0000 & 71.50 \pm 0.52 \\ & 0.5000 & 68.92 \pm 0.78 \\ & 0.2500 & 58.52 \pm 1.47 \\ & 0.1250 & 42.37 \pm 0.19 \\ & 0.0625 & 25.69 \pm 0.96 \\ 1 \text { (70) } & 1.0000 & 76.76 \pm 0.58 \\ & 0.5000 & 74.20 \pm 0.38 \\ & 0.2500 & 70.52 \pm 0.94 \\ & 0.1250 & 47.72 \pm 0.55 \\ 3 \text { (70) } & 0.0625 & 27.86 \pm 1.49 \\ & 1.0000 & 72.71 \pm 0.89 \\ & 0.5000 & 69.38 \pm 0.34 \\ & 0.2500 & 62.73 \pm 0.64 \\ 5(70) & 0.1250 & 55.99 \pm 0.54 \\ & 0.0625 & 35.25 \pm 1.22 \\ & 1.0000 & 74.36 \pm 0.67 \\ & 0.5000 & 70.35 \pm 0.66 \\ & 0.2500 & 68.89 \pm 0.77 \\ & 0.1250 & 52.39 \pm 0.52 \\ \text { BHT }(70) & 0.0625 & 33.42 \pm 1.50 \\ & 1.0000 & 71.53 \pm 0.97 \\ & 0.5000 & 68.27 \pm 0.61 \\ & 0.2500 & 63.62 \pm 0.98 \\ 9(70) & 0.1250 & 48.78 \pm 0.71 \\ & 0.0625 & 33.53 \pm 1.40 \\ & 1.0000 & 75.28 \pm 1.63 \\ & 0.5000 & 65.81 \pm 1.33 \\ & 0.2500 & 43.75 \pm 1.66 \\ & 0.1250 & 28.69 \pm 0.77 \\ & 0.0625 & 21.10 \pm 1.77 \\ & & \\ & 0.0500 & 77.93 \pm 0.85 \\ & 0.0250 & 63.89 \pm 0.95 \\ & 0.0125 & 43.79 \pm 1.40 \\ & 3.125 \times 10^{-3} & 35.54 \pm 0.63 \\ & & 22.28 \pm 1.12 \\ & & \\ & & \end{array}$

*1, 3, 5, 7 and 9 are the extraction time (days)while (30), (40), (50), (60) and (70) are temperature ( $p$ C).

${ }^{*} A A$ is antioxidant activity (\%).

For star anise soaked for 1,3 and 7 days, the yield of essential oil increased from $30^{\circ} \mathrm{C}$ to $60^{\circ} \mathrm{C}$. The extraction yield decreased with a further increase in temperature at $70^{\circ} \mathrm{C}$ due to loss of solvent and volatile oil at high temperature. The increase of extraction yield with increasing extraction time and temperature may be due to increased solubility and diffusion coefficient ${ }^{11}$. In this present study, the extraction temperature of $60^{\circ} \mathrm{C}$ and the extraction time of 7 days were the best condition to increase the extraction efficiency of star anise essential oil. It is therefore suggested that an extraction temperature of no higher than $60^{\circ} \mathrm{C}$ is employed.

\section{Qualitative test using DPPH on TLC}

All the star anise essential oils extracted at varied extraction times and temperatures showed antioxidant activities (Table 2). The degree of antioxidant activity of all samples was determined qualitatively from observation of the yellow colour intensity. Based on the yellow intensity of the bands on the chromatograms, the essential oil from star anise extracted at $60^{\circ} \mathrm{C}$ and $70^{\circ} \mathrm{C}$ for 1 day, 3 days, 5 days, 7 days and 9 days apparently showed stronger antioxidant activity than those extracted at $30^{\circ} \mathrm{C}$, $40^{\circ} \mathrm{C}$ and $50^{\circ} \mathrm{C}$.

Besides, it was observed that at least two different bands with antioxidant activity with different polarity were appeared on the TLC plate after spraying with DPPH and incubated for 30 minutes. (Figure 1-5). Samples extracted at $30^{\circ} \mathrm{C}$ for five days, $40^{\circ} \mathrm{C}$ for three days, $50^{\circ} \mathrm{C}$ and $60^{\circ} \mathrm{C}$ for nine days had two active bands while the rest of the samples showed three active bands with antioxidant activity (Table 3). The $R_{f}$ values of the active bands in all samples were in the range of 0.41 to 0.65 .

\section{Quantitative test using DPPH scavenging assay}

The radical scavenging activity or antioxidant activity (\%) of each concentration of oil and BHT were calculated using the formula (Equation 1) and the results were shown in Table 4. Generally, all the samples extracted at $303.3^{\circ} \mathrm{C}$ for $1,3,5,7$ and 9 days showed low antioxidant activity, which was below $60 \%$. Figure 6 showed that the antioxidant activity (\%) of essential oils extracted at $30^{\circ} \mathrm{C}$ increased steadily with increasing concentration from $6.25 \times 10^{-3} \mathrm{mg} / \mathrm{ml}$ to $1.00 \mathrm{mg} / \mathrm{ml}$. The antioxidant activity of each sample was then expressed as $\mathrm{EC}_{50}$, which is the concentration of sample required to decrease the initial DPPH free radical by $50 \%$.

It was observed that star anise essential oil extracted at $30^{\circ} \mathrm{C}$ for 1 day had the greatest $\mathrm{EC}_{50}$ value of $0.973 \mathrm{mg} / \mathrm{ml}$ (Table 5). This means that the essential oil extracted at $30^{\circ} \mathrm{C}$ for 1 day had lowest antioxidant activity as it required 0.973 $\mathrm{mg} / \mathrm{ml}$ to scavenge $50 \%$ of the free DPPH radicals. 
The $\mathrm{EC}_{50}$ values for samples extracted at $30^{\circ} \mathrm{C}$ for 3 days $(0.967 \mathrm{mg} / \mathrm{ml}), 5$ days $(0.928 \mathrm{mg} / \mathrm{ml}), 7$ days $(0.893 \mathrm{mg} / \mathrm{ml})$ and 9 days $(0.622 \mathrm{mg} / \mathrm{ml})$ were declined gradually. This indicated that the degree of antioxidant activity increased with increasing extraction time at $30^{\circ} \mathrm{C}$. This might be due to longer contact time of star anise with solvent and hence increased the rate of extraction of potential active

Table 5: $\mathrm{EC}_{50}$ of star anise essential oils extracted at $30^{\circ} \mathrm{C}$ for $1,3,5,7$ and 9 days

\begin{tabular}{ll}
\hline Samples & $\mathrm{EC}_{50}(\mathrm{mg} / \mathrm{ml})$ \\
\hline $1\left(30^{\circ} \mathrm{C}\right)$ & $0.973 \pm 0.56$ \\
$3\left(30^{\circ} \mathrm{C}\right)$ & $0.967 \pm 0.56$ \\
$5\left(30^{\circ} \mathrm{C}\right)$ & $0.928 \pm 0.54$ \\
$7\left(30^{\circ} \mathrm{C}\right)$ & $0.893 \pm 0.52$ \\
$9\left(30^{\circ} \mathrm{C}\right)$ & $0.622 \pm 0.36$ \\
\hline
\end{tabular}

${ }^{*} \mathrm{EC}_{50}$ defined as the concentration of essential oil in $\mathrm{mg} / \mathrm{ml}$ required to scavenge $50 \%$ of the DPPH radical

Table 7: $\mathrm{EC}_{50}$ of star anise essential oils extracted at $50^{\circ} \mathrm{C}$ for $1,3,5,7$ and 9 days

\begin{tabular}{ll}
\hline Samples & $\mathrm{EC}_{50}(\mathrm{mg} / \mathrm{ml})$ \\
\hline $1\left(50^{\circ} \mathrm{C}\right)$ & $0.098 \pm 0.06$ \\
$3\left(50^{\circ} \mathrm{C}\right)$ & $0.112 \pm 0.06$ \\
$5\left(50^{\circ} \mathrm{C}\right)$ & $0.133 \pm 0.08$ \\
$7\left(50^{\circ} \mathrm{C}\right)$ & $0.143 \pm 0.08$ \\
$9\left(50^{\circ} \mathrm{C}\right)$ & $0.099 \pm 0.06$ \\
\hline
\end{tabular}

${ }^{*} \mathrm{EC}_{50}$ defined as the concentration of essential oil in $\mathrm{mg} / \mathrm{ml}$ required to scavenge $50 \%$ of the DPPH radical

Table 9: $\mathrm{EC}_{50}$ of star anise essential oils extracted at $70^{\circ} \mathrm{C}$ for $1,3,5,7$ and 9 days

\begin{tabular}{lc}
\hline Samples & $\mathrm{EC}_{50}(\mathrm{mg} / \mathrm{ml})$ \\
\hline $1\left(70^{\circ} \mathrm{C}\right)$ & $0.135 \pm 0.08$ \\
$3\left(70^{\circ} \mathrm{C}\right)$ & $0.100 \pm 0.06$ \\
$5\left(70^{\circ} \mathrm{C}\right)$ & $0.116 \pm 0.07$ \\
$7\left(70^{\circ} \mathrm{C}\right)$ & $0.130 \pm 0.08$ \\
$9\left(70^{\circ} \mathrm{C}\right)$ & $0.310 \pm 0.18$ \\
\hline
\end{tabular}

${ }^{\star} \mathrm{EC}_{50}$ defined as the concentration of essential oil in $\mathrm{mg} / \mathrm{ml}$ required to scavenge $50 \%$ of the DPPH radical compounds with antioxidant activity ${ }^{12}$. The ascending order for the antioxidant activity was $1\left(30^{\circ} \mathrm{C}\right)<3$ $\left(30^{\circ} \mathrm{C}\right)<5\left(30^{\circ} \mathrm{C}\right)<7\left(30^{\circ} \mathrm{C}\right)<9\left(30^{\circ} \mathrm{C}\right)$.

The antioxidant activity (\%) of all the star anise essential oil extracted at $40^{\circ} \mathrm{C}$ was above 60 $\%$ (Table 4 and Figure 7). The $\mathrm{EC}_{50}$ value for essential oil extracted at $40^{\circ} \mathrm{C}$ for 1 day was $0.585 \mathrm{mg} / \mathrm{ml}$ (Table

Table 6: $\mathrm{EC}_{50}$ of star anise essential oils extracted at $40^{\circ} \mathrm{C}$ for $1,3,5,7$ and 9 day

\begin{tabular}{lc}
\hline Samples & $\mathrm{EC}_{50}(\mathrm{mg} / \mathrm{ml})$ \\
\hline $1\left(40^{\circ} \mathrm{C}\right)$ & $0.585 \pm 0.34$ \\
$3\left(40^{\circ} \mathrm{C}\right)$ & $0.391 \pm 0.23$ \\
$5\left(40^{\circ} \mathrm{C}\right)$ & $0.476 \pm 0.27$ \\
$7\left(40^{\circ} \mathrm{C}\right)$ & $0.528 \pm 0.30$ \\
$9\left(40^{\circ} \mathrm{C}\right)$ & $0.583 \pm 0.34$ \\
\hline
\end{tabular}

${ }^{*} \mathrm{EC}_{50}$ defined as the concentration of essential oil in $\mathrm{mg} / \mathrm{ml}$ required to scavenge $50 \%$ of the DPPH radical

Table 8: $\mathrm{EC}_{50}$ of star anise essential oils extracted at $60^{\circ} \mathrm{C}$ for $1,3,5,7$ and 9 days

\begin{tabular}{lc}
\hline Samples & $\mathrm{EC}_{50}(\mathrm{mg} / \mathrm{ml})$ \\
\hline $1\left(60^{\circ} \mathrm{C}\right)$ & $0.089 \pm 0.05$ \\
$3\left(60^{\circ} \mathrm{C}\right)$ & $0.221 \pm 0.13$ \\
$5\left(60^{\circ} \mathrm{C}\right)$ & $0.153 \pm 0.09$ \\
$7\left(60^{\circ} \mathrm{C}\right)$ & $0.173 \pm 0.10$ \\
$9\left(60^{\circ} \mathrm{C}\right)$ & $0.583 \pm 0.34$ \\
\hline
\end{tabular}

${ }^{*} \mathrm{EC}_{50}$ defined as the concentration of essential oil in $\mathrm{mg} / \mathrm{ml}$ required to scavenge $50 \%$ of the DPPH radical

Table 10: $\mathrm{EC}_{50}$ of $\mathrm{BHT}$

\begin{tabular}{lc}
\hline Positive control & $\mathrm{EC}_{50}(\mathrm{mg} / \mathrm{ml})$ \\
\hline $\mathrm{BHT}$ & $0.016 \pm 0.01$ \\
\hline${ }^{*} \mathrm{EC}_{50}$ defined as the concentration of BHT in $\mathrm{mg} / \mathrm{ml}$ required \\
to scavenge $50 \%$ of the DPPH radical
\end{tabular}


6). The $\mathrm{EC}_{50}$ value dropped to $0.391 \mathrm{mg} / \mathrm{ml}$ when the there was an increase in $\mathrm{EC}_{50}$ values until day 9 . The essential oil extracted at $40^{\circ} \mathrm{C}$ for 3 days. After that, increase of $\mathrm{EC}_{50}$ values corresponded to a weaker

Table 11: Retention time, peak area, area percentage and concentration (\%) of trans-Anethole

\begin{tabular}{lcccc}
\hline Samples & $\begin{array}{c}\text { Retention } \\
\text { time (min) }\end{array}$ & $\begin{array}{c}\text { Peak area } \\
\text { (mAU) }\end{array}$ & Area \% & $\begin{array}{c}\text { Concentration of } \\
\text { trans-Anethole }(\%)\end{array}$ \\
\hline $1\left(30^{\circ} \mathrm{C}\right)$ & 36.447 & 42026575 & 87.10 & 45.03 \\
$3\left(30^{\circ} \mathrm{C}\right)$ & 36.494 & 44773802 & 88.65 & 47.77 \\
$5\left(30^{\circ} \mathrm{C}\right)$ & 35.969 & 51472038 & 86.10 & 54.47 \\
$7\left(30^{\circ} \mathrm{C}\right)$ & 35.892 & 47123286 & 83.59 & 50.12 \\
$9\left(30^{\circ} \mathrm{C}\right)$ & 35.953 & 45643690 & 88.22 & 48.64 \\
$1\left(40^{\circ} \mathrm{C}\right)$ & 36.159 & 74506751 & 90.59 & 77.51 \\
$3\left(40^{\circ} \mathrm{C}\right)$ & 35.643 & 77681832 & 83.98 & 80.68 \\
$5\left(40^{\circ} \mathrm{C}\right)$ & 35.416 & 77231780 & 81.75 & 80.23 \\
$7\left(40^{\circ} \mathrm{C}\right)$ & 35.688 & 75850066 & 83.65 & 78.85 \\
$9\left(40^{\circ} \mathrm{C}\right)$ & 35.480 & 72687388 & 81.03 & 75.69 \\
$1\left(50^{\circ} \mathrm{C}\right)$ & 36.085 & 87166545 & & 90.17 \\
$3\left(50^{\circ} \mathrm{C}\right)$ & 35.674 & 86293969 & 91.87 & 89.29 \\
$5\left(50^{\circ} \mathrm{C}\right)$ & 35.515 & 85001535 & 82.86 & 88.00 \\
$7\left(50^{\circ} \mathrm{C}\right)$ & 35.695 & 84310937 & 79.95 & 87.31 \\
$9\left(50^{\circ} \mathrm{C}\right)$ & 35.501 & 87883643 & 80.82 & 90.88 \\
$1\left(60^{\circ} \mathrm{C}\right)$ & 35.593 & 88605132 & 77.66 & 91.61 \\
$3\left(60^{\circ} \mathrm{C}\right)$ & 35.602 & 80384982 & 81.01 & 83.38 \\
$5\left(60^{\circ} \mathrm{C}\right)$ & 36.635 & 83499402 & 81.49 & 86.50 \\
$7\left(60^{\circ} \mathrm{C}\right)$ & 36.387 & 81248763 & 77.29 & 84.25 \\
$9\left(60^{\circ} \mathrm{C}\right)$ & 36.217 & 82197107 & 85.26 & 85.20 \\
$1\left(70^{\circ} \mathrm{C}\right)$ & 35.984 & 84675286 & 84.13 & 87.68 \\
$3\left(70^{\circ} \mathrm{C}\right)$ & 35.777 & 86826860 & 78.16 & 89.83 \\
$5\left(70^{\circ} \mathrm{C}\right)$ & 35.505 & 86137109 & 80.11 & 89.14 \\
$7\left(70^{\circ} \mathrm{C}\right)$ & 36.143 & 84713397 & 81.17 & 87.71 \\
$9\left(70^{\circ} \mathrm{C}\right)$ & 35.960 & 80227656 & 80.90 & 83.23 \\
& & & & \\
\hline & & & & \\
\hline
\end{tabular}

Table 12: GC-MS integration peak list of star anise

\begin{tabular}{lcccccc}
\hline Peak & Start & Retention Time $(\min )$ & End & Height & Area & Area \% \\
\hline 1 & 1.207 & 1.254 & 1.278 & 12317328.01 & 20705118.73 & 26.51 \\
2 & 1.278 & 1.296 & 1.320 & 1007344.37 & 1259429.21 & 1.61 \\
3 & 1.320 & 1.333 & 1.405 & 1399943.10 & 1631685.47 & 2.09 \\
4 & 1.471 & 1.490 & 1.508 & 872502.26 & 846001.88 & 1.08 \\
5 & 1.580 & 1.598 & 1.677 & 2163750.47 & 2163120.54 & 2.77 \\
6 & 6.921 & 6.982 & 7.018 & 4293290.40 & 9256418.18 & 11.85 \\
7 & 7.018 & 7.042 & 7.109 & 759609.95 & 1450076.10 & 1.86 \\
8 & 8.704 & 8.752 & 8.855 & 1110739.09 & 2250361.35 & 2.88 \\
9 & 11.351 & 11.411 & 11.495 & 2060092.29 & 4496388.18 & 5.76 \\
10 & 13.672 & 13.84 & 13.912 & 15702253.33 & 78099815.51 & 100.00 \\
\hline
\end{tabular}




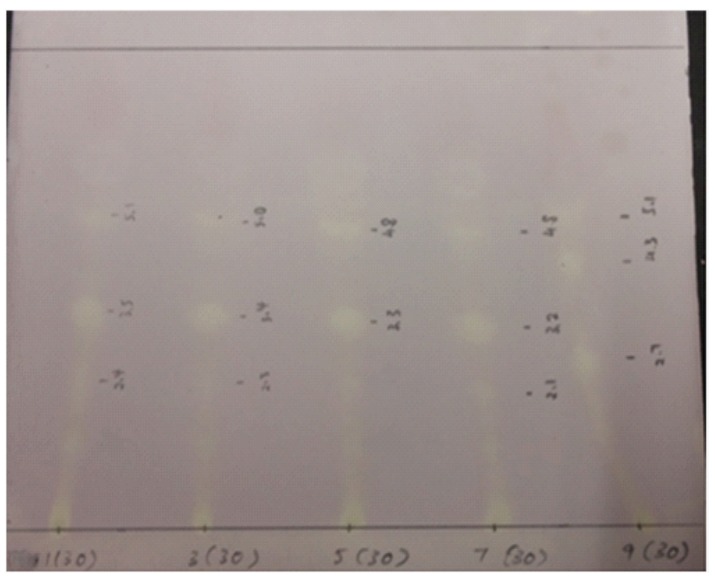

Fig. 1: Chromatogram of essential oil extracted at $30^{\circ} \mathrm{C}$ for 1 day, 3 days, 5 days, 7 days and 9 days (from left to right)

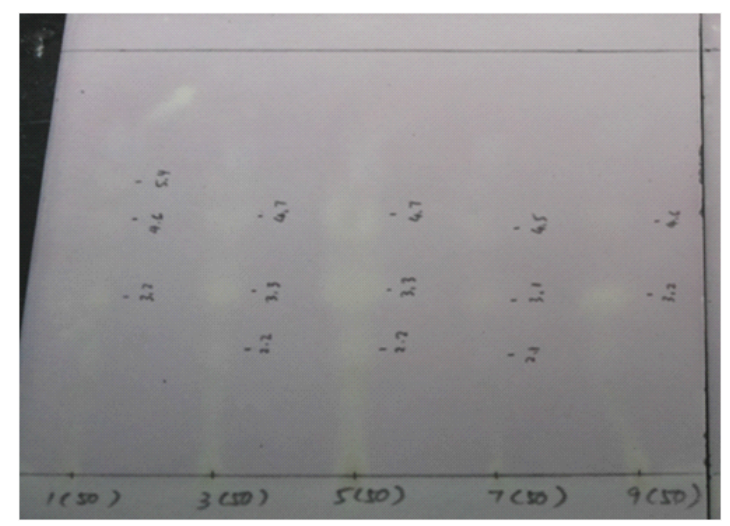

Fig. 3: Chromatogram of essential oil extracted at $50^{\circ} \mathrm{C}$ for 1 day, 3 days, 5 days, 7 days and 9 days (from left to right)

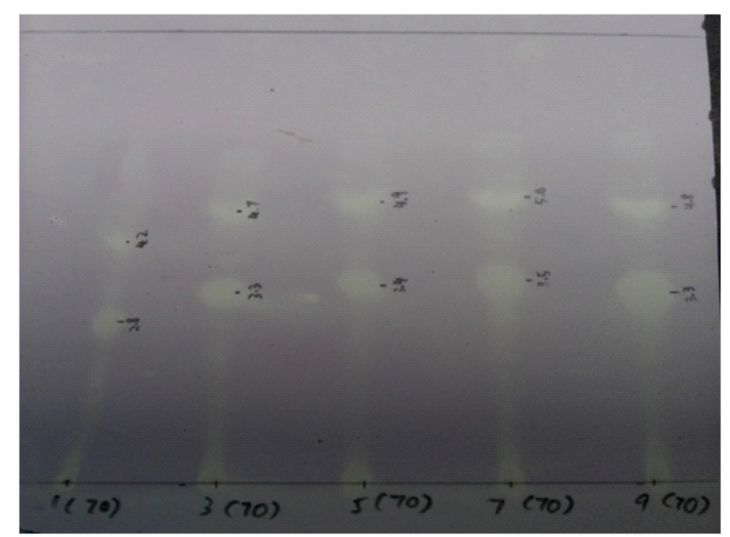

Fig. 5: Chromatogram of essential oil extracted at $70^{\circ} \mathrm{C}$ for 1 day, 3 days, 5 days, 7 daysand 9 days (from left to right)

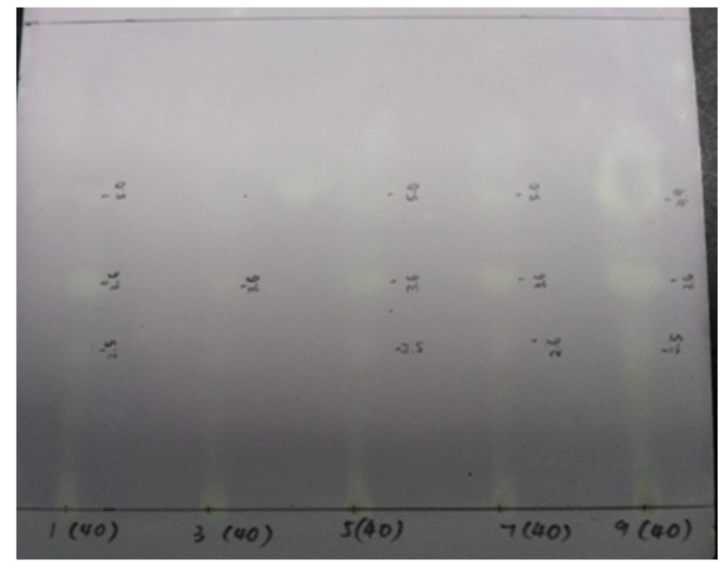

Fig. 2: Chromatogram of essential oil extracted at $40^{\circ} \mathrm{C}$ for 1 day, 3 days, 5 days, 7 days and 9 days (from left to right)

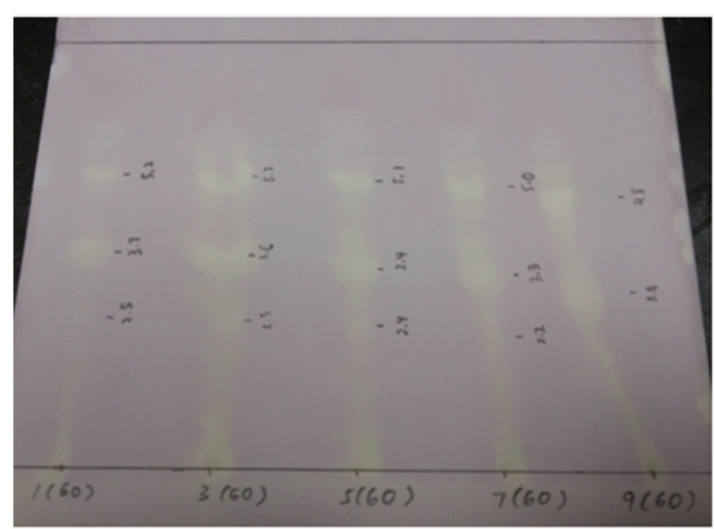

Fig. 4: Chromatogram of essential oil extracted at $60^{\circ} \mathrm{C}$ for 1 day, 3 days, 5 days, 7 days and 9 days (from left to right)

Antioxid ant Activities (\%) of Star Anise Essential Oil Against Concentration (mg/ml)

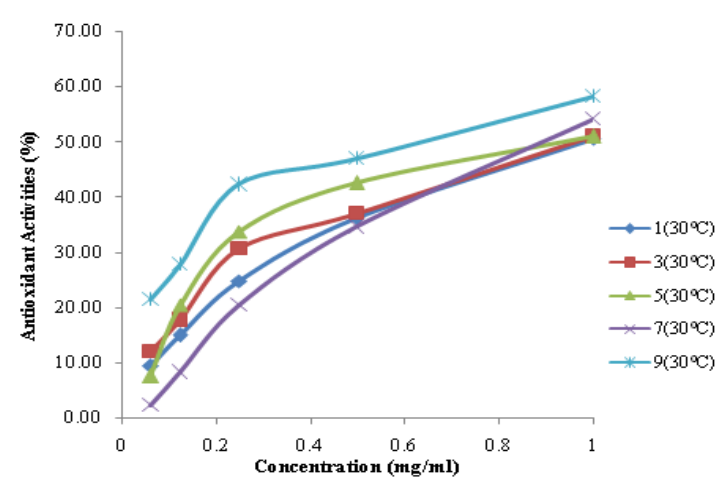

Fig. 6: DPPH radical scavenging activity of star anise essential oils extracted at $30^{\circ} \mathrm{C}$ for $1,3,5,7$ and 9 days 
Antioxidant Activities (\%) of Star Anise Essential Oil Against Concentration $(\mathbf{m g} / \mathrm{ml})$

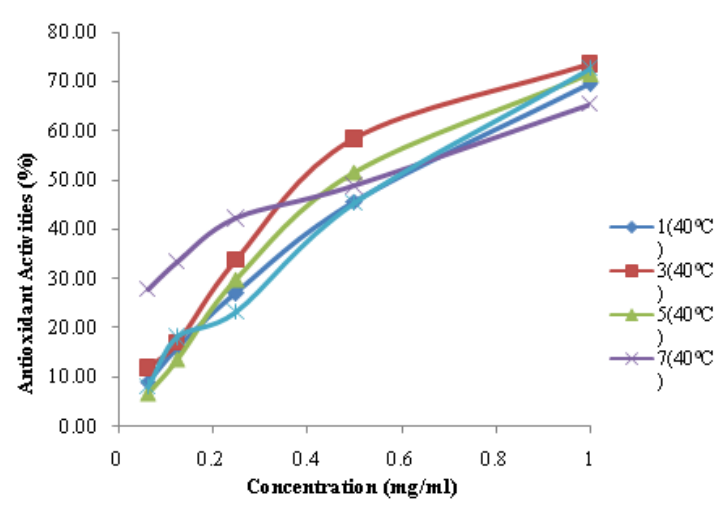

Fig. 7: DPPH radical scavenging activity of star anise essential oils extracted at $40^{\circ} \mathrm{C}$ for 1 , $3,5,7$ and 9 days

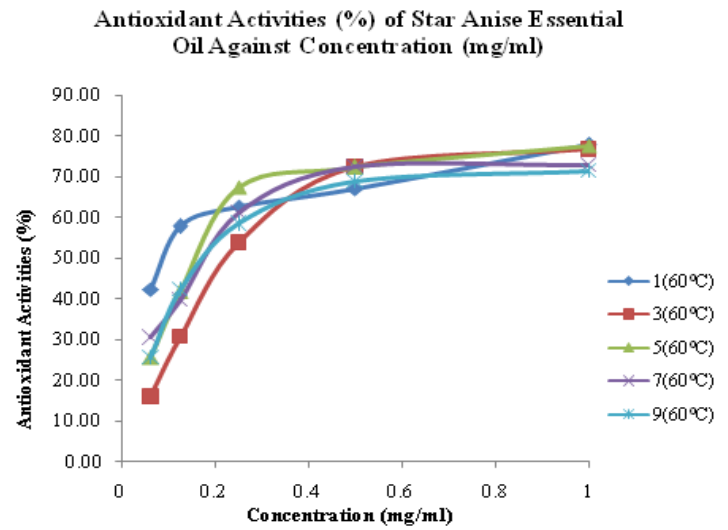

Fig. 9: DPPH radical scavenging activity of star anise essential oils extracted at $60^{\circ} \mathrm{C}$ for 1,3 , 5,7 and 9 days.

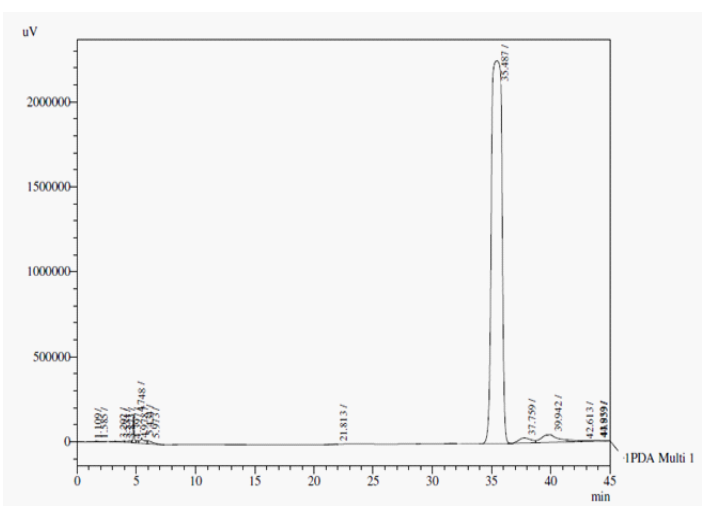

Fig. 11: HPLC chromatogram for standard trans-Anethole

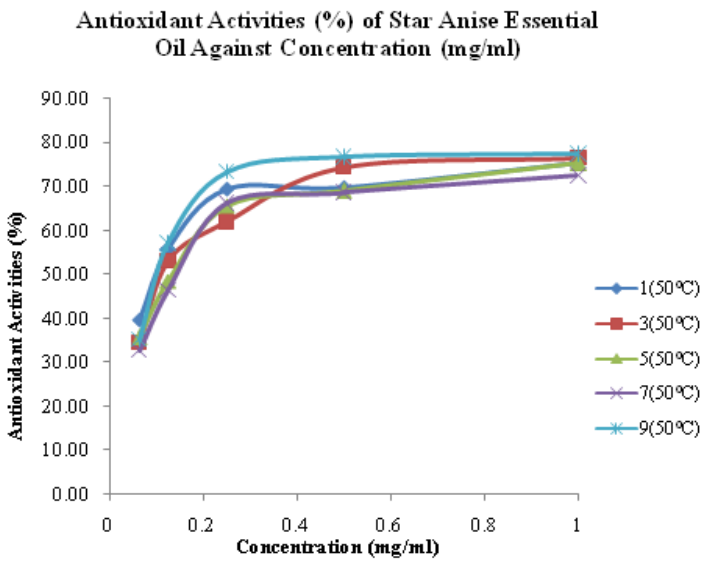

Fig. 8: DPPH radical scavenging activity of star anise essential oils extracted at $50^{\circ} \mathrm{C}$ for $1,3,5,7$ and 9 days

Antioxidant Activities (\%) of Star Anise Essential Oil Against Concentration (mg/ml)

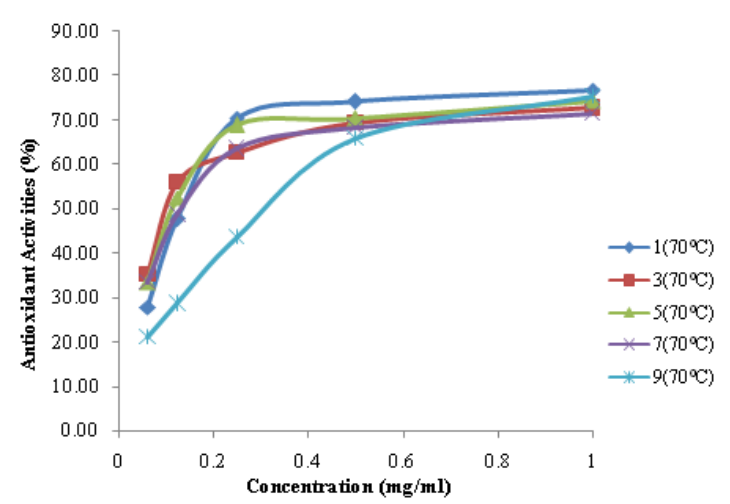

Fig. 10: DPPH radical scavenging activity of star anise essential oils extracted at $70^{\circ} \mathrm{C}$ for $1,3,5,7$ and 9 days

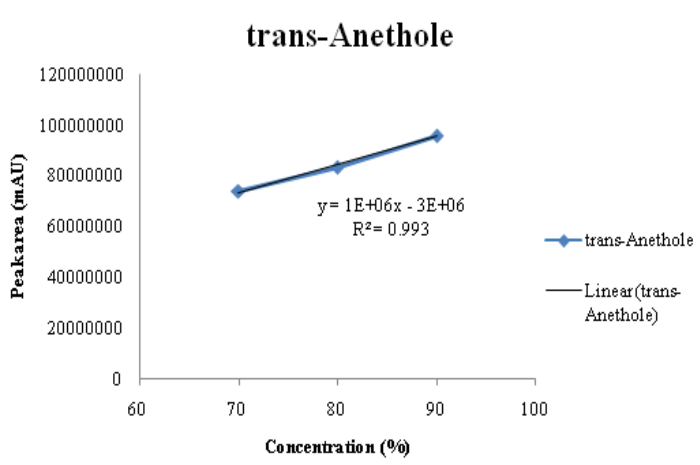

Fig. 12: Standard curve of trans-Anethole 


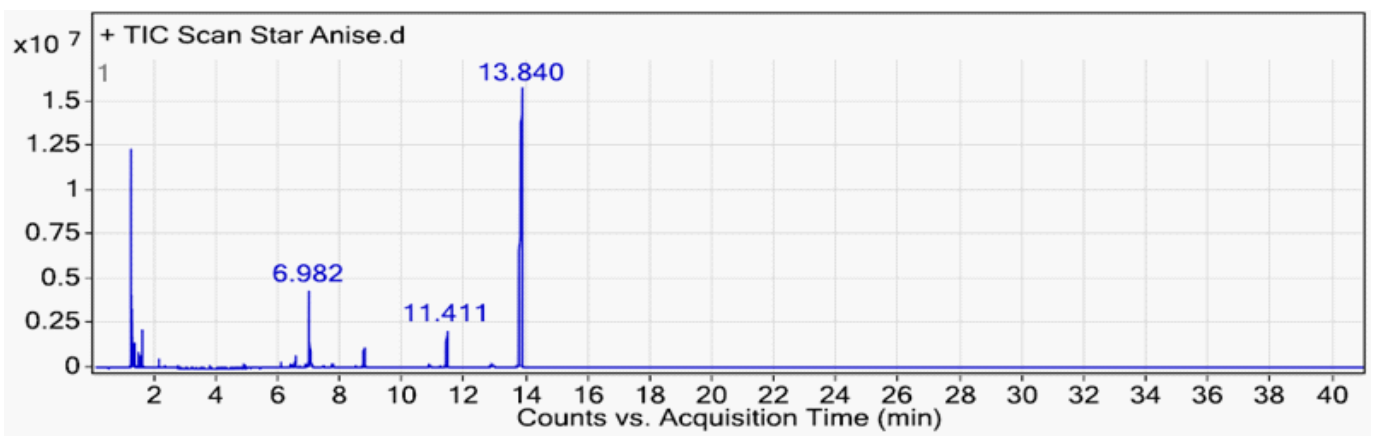

Fig. 13: GC-MS chromatogram of Star Anise

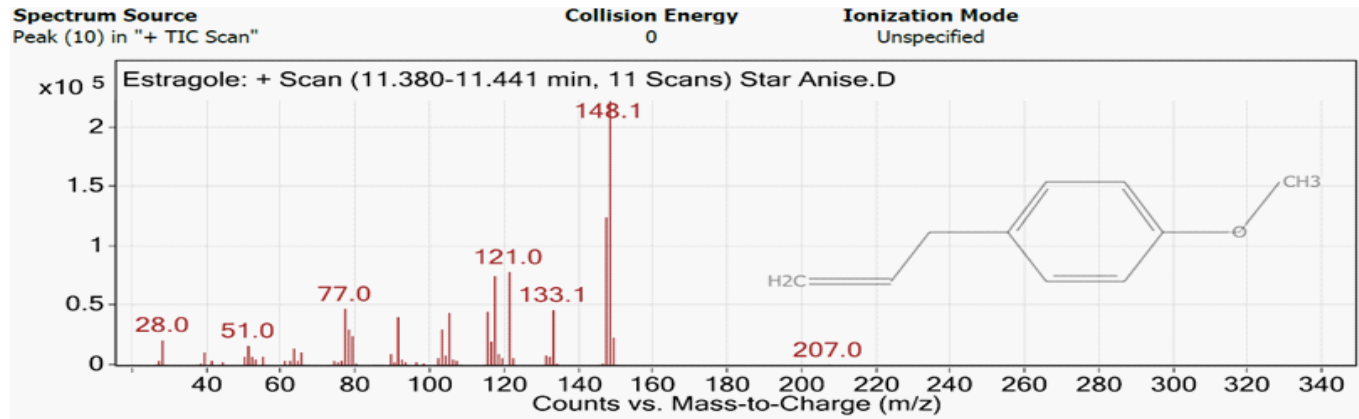

Fig. 14: GC-MS spectrum source of Estragole at peak 10

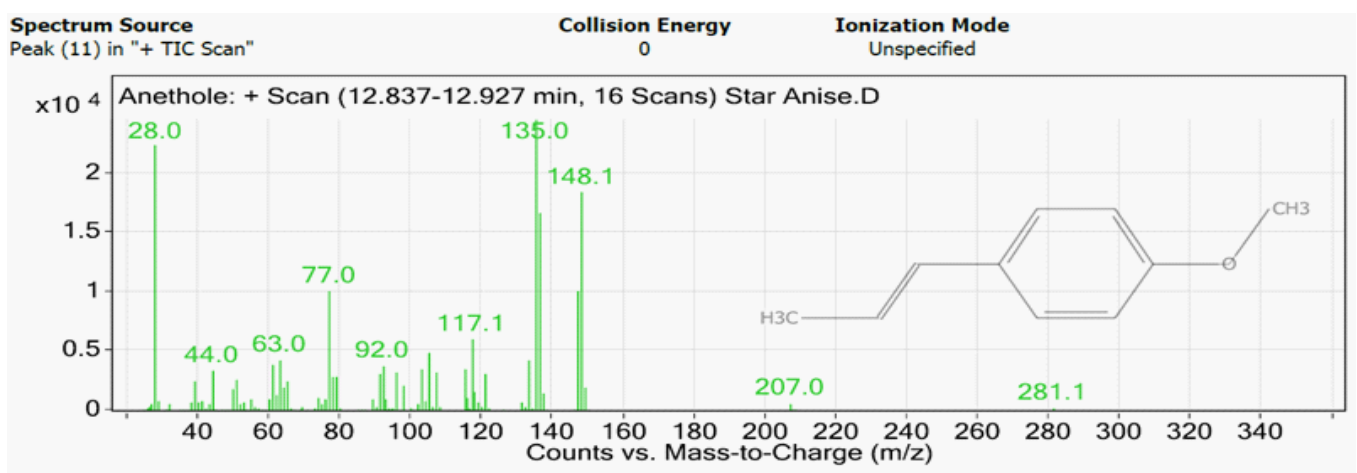

Fig. 15: GC-MS spectrum source of Anethole at peak 11

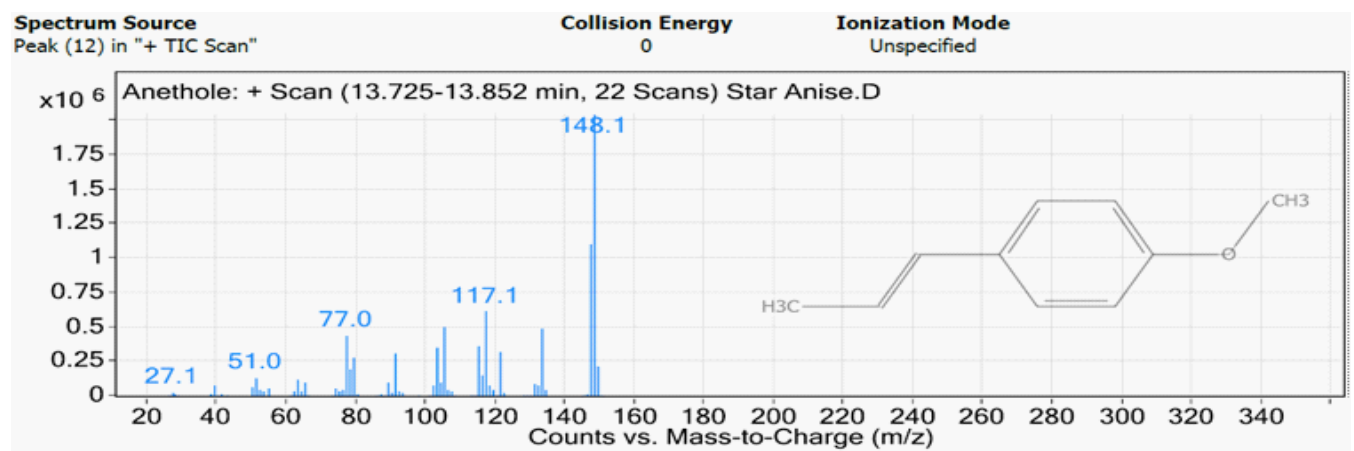

Fig. 16: GC-MS spectrum source of Anethole at peak 12 
antioxidant.The order of antioxidant capacity for samples extracted at $40^{\circ} \mathrm{C}$ was $1\left(40^{\circ} \mathrm{C}\right)<9\left(40^{\circ} \mathrm{C}\right)$ $<7\left(40^{\circ} \mathrm{C}\right)<5\left(40^{\circ} \mathrm{C}\right)<3\left(40^{\circ} \mathrm{C}\right)$.

In general, the antioxidant activity (\%) of star anise essential oils extracted at temperature of $50^{\circ} \mathrm{C}$ was higher than $70 \%$ (Table 4 and Figure 8). According to Table 7, essential oil extracted at $50 \mathrm{p} \mathrm{C}$ for 1 day showed $\mathrm{EC}_{50}$ value of $0.098 \pm 0.06$ $\mathrm{mg} / \mathrm{ml}$. The concentration of essential oil needed to scavenge $50 \%$ of DPPH radical increased from day 1 to day 7. However, there was a marked decrease of concentration of essential oil to scavenge $50 \%$ of the radicals. The antioxidant power of sample extracted at $50^{\circ} \mathrm{C}$ for 9 days $(0.099 \pm 0.06 \mathrm{mg} / \mathrm{ml})$ was as good as the sample extracted for 1 day. In other words, essential oil extracted at $50^{\circ} \mathrm{C}$ for 1 day was the strongest antioxidant, followed by those essentail oil extracted at 9 days, 3 days, 5 days and 7 days.

All the essential oils extracted at $60^{\circ} \mathrm{C}$ showed antioxidant activity greater than $70 \%$ (Table 4 and Figure 9). The results in Table 8 showed that essential oils extracted at $60^{\circ} \mathrm{C}$ for 1 day was the strongest antioxidant. This was because only $0.089 \pm 0.05 \mathrm{mg} /$ $\mathrm{ml}$ of essential oil was needed for the scavenging activity of free radicals. The antioxidant power was decreasing in the order $1\left(60^{\circ} \mathrm{C}\right)>5\left(60^{\circ} \mathrm{C}\right)>7\left(60^{\circ} \mathrm{C}\right)$ $>3\left(60^{\circ} \mathrm{C}\right)>9\left(60^{\circ} \mathrm{C}\right)$.

Compared with essential oil extracted at 60 $p C$ for 1 day $\left(E C_{50}\right.$ value $\left.=0.089 \pm 0.05\right)$, essential oil extracted at $60 \mathrm{p} \mathrm{C}$ for 9 days $\left(\mathrm{EC}_{50}\right.$ value $=0.583$ \pm 0.34 ) showed a significant difference in term of concentration in $\mathrm{mg} / \mathrm{ml}$ necessary to scavenge 50 $\%$ of the DPPH radicals. The antioxidant activities of star anise essential oils extracted at $60^{\circ} \mathrm{C}$ were undulated with increasing extraction time. This might be due to the possible synergistics effects of different compounds on the total oil antioxidant activity ${ }^{13}$.

All the star anise essential oils extracted at $70^{\circ} \mathrm{C}$ for varied extraction time showed antioxidant activity (\%) above $70 \%$ (Table 4 and Figure 10). Since lower $\mathrm{EC}_{50}$ value indicated higher antioxidant activity, essential oil extracted at 70 p C for 3 days exhibited stronger antioxidant activity than essential oil extracted for 1 day. The $\mathrm{EC}_{50}$ value for essential oil extracted for 3 days and 1 day were $0.100 \pm$ $0.06 \mathrm{mg} / \mathrm{ml}$ and $0.135 \pm 0.08 \mathrm{mg} / \mathrm{ml}$ respectively as shown in Table 9. Essential oils extracted more than 3 days, which were 5 days, 7 days and 9 days showed decreasing of antioxidant power as the $\mathrm{EC}_{50}$ value increased markedly from $0.100 \pm 0.06 \mathrm{mg} / \mathrm{ml}$ to $0.310 \pm 0.18 \mathrm{mg} / \mathrm{ml}$. The antioxidant activity was in order $3\left(70^{\circ} \mathrm{C}\right)>5\left(70^{\circ} \mathrm{C}\right)>7\left(70^{\circ} \mathrm{C}\right)>1\left(70^{\circ} \mathrm{C}\right)$ $>9\left(70^{\circ} \mathrm{C}\right)$.

There was an increase in antioxidant activities of star anise essential oils from $30^{\circ} \mathrm{C}$ to $50^{\circ} \mathrm{C}$. This might due to ambient or physiological temperatures could reduce thermal degradation of volatile essential oil ${ }^{14}$. The antioxidant activities of star anise essential oils decreased slightly at $60^{\circ} \mathrm{C}$. This was in agreement with Dent and research group (2012), stated that degradation of phenolic compounds may occured at temperature of $60^{\circ} \mathrm{C}^{11}$. At temperature $70^{\circ} \mathrm{C}$, the antioxidant activities of star anise essential oils increased moderately. Typically, antioxidant activity decreased with increasing temperature, but it does not have universal validity ${ }^{15}$.

In this quatitative antioxidant test using DPPH method, a well known synthetic antioxidant, namely butylated hydroxytoluene $(\mathrm{BHT})$ was used as positive control. The concentration of $\mathrm{BHT}$ for a $50 \%$ scavenging activity was about $0.018 \mathrm{mg} / \mathrm{ml}$ [16]. In this study, $0.016 \pm 0.01 \mathrm{mg} / \mathrm{ml}$ of $\mathrm{BHT}$ was required in scavenging action towards DPPH free radicals (Table 10).By comparing the antioxidant activity of star anise essential oil with $\mathrm{BHT}$, it was revealed that antioxidant activity of essential oil from star anise was comparable with the synthetic antioxidant $\mathrm{BHT}$, particularly essential oils that were extracted at temperature $50^{\circ} \mathrm{C}$ and $60^{\circ} \mathrm{C}$.

\section{HPLC and GC-MS analysis}

The HPLC chromatogram of standard transAnethole with retention time of 35.487 minutes was shown in Figure 11. It was observed that the highest peaks of all samples have a retention time near to the retention time of standard trans-Anethole, which was around \pm 35 minutes. Similarities of the highest peak and retention time between samples and standard trans-Anethole in the HPLC chromatogram confirmed that trans-Anethole was present in star anise essential oil. In order to identify the concentration (\%) of trans-Anethole present in all the essential oils, a standard curve of trans-Anethole was plotted (Figure 12). The retention times, peak areas, area 
percentage and concentration (\%) of trans-Anethole for all samples were shown in Table 11.

All the star anise essential oils had high area percentage of trans-Anethole, which was ranged from $77.29 \%$ to $91.87 \%$. High percentage area indicated trans-Anethole was the most abundant compounds in all the star anise essential oils. Similar results were reported previously by Chempakam and Balaji (2008), stated that the main component of star anise essential oil is transAanethole, which accounts for 80-90 \% ${ }^{4}$. From GCMS analysis, Estragole was found to have the most significant peak with peak area $100 \%$ at retention time 13.840 minutes as shown in Figure 13 and 14 and Table 12.Estragole was found at the tenth peak. Anethole was also found at two peaks which were peak 11 and 12 as shown in Figure 15 and Figure 16. Thus, the data validates the presence of Anethole in the star anise sample.

In addition, it was observed that the concentration (\%) of trans-Anethole in the star anise essential oils varied considerably as function of temperature and extraction time. Generally, star anise essential oils extracted at $40^{\circ} \mathrm{C}, 50^{\circ} \mathrm{C}, 60^{\circ} \mathrm{C}$ and $70^{\circ} \mathrm{C}$ contained relatively high concentration (\%) of trans-Anethole compared to essential oils extracted at $30^{\circ} \mathrm{C}$. As temperature increases, higher mass fraction of trans-Anethole was extracted. It was in agreement with Chen and co-workers' finding (2007), which concluded that higher temperature will reduce the solvent viscosity and facilitate the diffusion of molecules, resulting to an increase of extraction efficiency ${ }^{17}$.

Besides, it was found that the concentration (\%) of trans-Anethole corresponded to the antioxidant activities of star anise essential oils. This statement was in agreement with Padmashree and research group (2007), reported that the antioxidant activity is due to high percentage of trans-Anethole, which is more than $80 \%{ }^{18}$. In the present study, star anise essential oil extracted at $60^{\circ} \mathrm{C}$ for 1 day has the highest concentration of trans-Anethole (91.61 $\%)$ and antioxidant activity $\left(\mathrm{EC}_{50}=0.089 \mathrm{mg} / \mathrm{ml}\right)$ while star anise essential oil extracted at $30^{\circ} \mathrm{C}$ for 1 day has the lowest concentration of trans-Anethole $(45.03 \%)$ and antioxidant activity $\left(\mathrm{EC}_{50}=0.973 \mathrm{mg} /\right.$ $\mathrm{ml})$. Therefore, it might be possible to infer that trans-Anethole found in the samples contributed to the antioxidant activities of the essential oils.

\section{CONCLUSION}

Essential oil from star anise was successfully extracted using solvent extraction method. Different extraction times ( 1 day, 3 days, 5 days, 7 days and 9 days) and temperatures $\left(30^{\circ} \mathrm{C}, 40^{\circ} \mathrm{C}, 50^{\circ} \mathrm{C}\right.$, $604.0^{\circ} \mathrm{C}$ and $70^{\circ} \mathrm{C}$ )did affect the yield of essential oil. The best condition to obtain the highest yield (8.56\%) of essential oil was at temperature of $60^{\circ} \mathrm{C}$ with an extraction time of 7 days. A rapid screening using DPPH assay on TLC showed thatat least two different yellow spots with antioxidant activity with different polarity were appeared on all TLC plates at solvent system 95:5, v/v toluene/ ethyl acetate. In addition, the highest antioxidant activity of star anise essential oil was observed when the sample was extracted at $60^{\circ} \mathrm{C}$ for 1 day $\left(E_{50}\right.$ value $=0.089 \pm 0.05$ $\mathrm{mg} / \mathrm{ml}$ ).From the HPLC analysis results, samples with higher trans-Anethole concentration have higher antioxidant activities. Star anise essential oil extracted at $60^{\circ} \mathrm{C}$ for 1 day showed the highest concentration (\%) of trans-Anethole $(91.61 \%)$ while essential oil extracted at $30^{\circ} \mathrm{C}$ for 1 day showed the lowest concentration (\%) of trans-Anethole (45.03 $\%)$. The antioxidant activity of the high level of transAnethole-containing star anise essential oil was comparable with the synthetic antioxidant BHT.

\section{ACKNOWLEDGEMENTS}

The authors express their sincere appreciation to Faculty of Agro Based Industry, Universiti Malaysia Kelantan, Jeli Campus for the financial support which made this study possible.

\section{REFERENCES}

1. Ito, N., Hirose, M., Fukushima, S., Tsuda, H., \&Tatematsu, M., Studies on antioxidants: their carcinogenic and modifying effects on chemical carcinogenesis. Food and Chemical Toxicology, 1986, 24(10-11), 1071.

2. Pokorny, J., Natural antioxidant for food use. 
Trends in Food Science Technology, 1991, 9, 223-227.

3. Nanditha, B., \&Prabhasankar, P., Antioxidants in bakery products: a review. Critical Reviews in Food Science and Nutrition, 2009, 49, 1-27.

4. Chempakam, B. \&Balaji, S., Star Anise.In Chemistry of spices. United Kingdom: CAB International. 2008, 319-330.

5. Ong, H.C., BungaLawang. In H.C., Ong (Ed.), Rempah-ratus: KhasiatMakanan \& Ubatan. Malaysia: Utusan Publication \& Distributors Sdn. Bhd. 2008, 94.

6. Thuat, B.Q., \& Ngoc, B.T.B., Obtaining Essential Oil and Shikimic Acid from Star Anise Fruit (Illiciumverum Hook). VNU Journal of Science and Technology, 2010. 26, 110113.

7. Saleh, M.A., Clark, S., Woodard, B., \&DeoluSobogun, S.A., Antioxidant and free radical scavenging activities of essential oils. Ethnicity and Disease, 2010, 20, 78-82.

8. Brand-Williams, W., Cuvelier, M.E., \&Berset, C., Use of a free radical method to evaluate antioxidant activity. Journal of Food Science Technology, 1995, 28, 25-30.

9. Ngoc, B.T.B., Research on technology of obtaining, refining stra anise essential oil and converted it into anisaldehyde to enhance the economic value of Vietnamese star anise plant. Unpublished master's thesis.Hanoi University of Polytechnique, Vietnam, 2006.

10. Abu-Darwish, M.Z., Abu, D.B., Mufeed, M., Abdel, R.A., Al-Tawaha, S., \& Al-dalain., Trace element contents and essential oil yields from wild thyme plant (Thymus serpyllum L.) grown at different natural variable environments, Jordon. Journal of Food, Agriculture and
Environment, 2009, 7(3\&4), 920-924.

11. Dent, M., Dragovi-Uzelac, V., Peni, M., Brni, M., Bosiljkov, T., \&Levaj, B., Effect of Extraction Solvents, Temperature and Time on the composition and Mass Fraction of Polyphenols of Dalmatian Wild Sage (Salvia officinalis L.). Food Technology \& Biotechnology, 2012, 51(1), 84.

12. Kumar, K.S., Extraction of essential oil using steam distillation. Unpublished bachelor's thesis. National Institute of Technology Rourkela, India, 2010.

13. Abdalla, A.E., \&Roozen, J.P., Effect of plant extracts on the oxidative stability of sunflower oil and emulsion. Food Chemistry, 1999, 64, 323-329.

14. Laguerre, M., Lecomte, J., \& Villeneuve, P., Evaluation of the ability of antioxidants to counteract lipid oxidation: Existing methods, new trends and challenges. Progress in Lipid Research, 2007, 46, 244-282.

15. Pokorny, J., Addition of antioxidants for food stabilization to control antioxidative rancidity. Journal of Food Science, 1986, 4, 299-307.

16. Kulisic, T., Radonic, A., Katalinic, V., \& Milos, M., Use of different methods for testing antioxidative activity of oregano essential oil. Food Chemistry, 2003, 85, 633-640.

17. Chen, Y., Xie, M.Y., \& Gong, X.F., Microwaveassisted extraction used for isolation of total triterpenoidsaponins from Ganodermaatrum. Journal of Food Engineering, 2007, 81, 162170.

18. Padamshree, A., Roopa, N., Semval, A.D., Sharma, G.K., Agathian, V., \&Bawa, A.S., Star anise (Illiciumverum) and black (Carumnigrum) as natural antioxidants. Food Chemistry, 2007, 104(1), 59-66. 